\title{
Taxpayers Attitude Towards the New Tax Proclamation in Ethiopia in Case of Employment Income Taxpayers in Debre Markos Town
}

\author{
Yichilal Simegn Filatie \\ Debre Markos University, College Of Business and Economics, Department Of Accounting and Finance \\ Debre Markos, Ethiopia
}

\begin{abstract}
The objective of this study is to assess the taxpayers' attitude towards the new tax system as per the new tax proclamation in Ethiopia in relation to tax fairness, tax complexity, and tax efficiency. A survey using selfadministered questionnaire has been used to collect the primary data. The survey used 85 respondents among employment income tax payers in Debre Markos town. The collected data are presented using tables and percentages. The study reveals that, the employment tax payers believed that the new tax proclamation is fair in terms of horizontal, vertical and administrative fairness. Finally, the study concludes that the new tax proclamation system is reasonably fair in terms of horizontal, vertical and administrative fairness in the mind of tax payers. But it is complex and economically inefficient from tax payers' point of view. Based on the findings obtained and conclusions drawn the researcher recommended that the tax authority in particular and government in general shall try to empower the tax payers with knowledge and change their attitude through sustainable awareness creation programs.
\end{abstract}

Keywords -Attitude, Tax fairness, Tax complexity, Tax efficiency

DOI: $10.7176 / \mathrm{JESD} / 10-23-06$

Publication date: December $31^{\text {st }} 2019$

\subsection{Introduction}

All the powers of the government other than its authority to declare war, none bears so incisively up on the welfare Of citizens, both privately \& in their Economic enterprise, as does its power to tax (Lamonz, 1992) taxation is one of the important element in managing national income, especially in Developed countries and has helped an important role in civilized societies since their birth thousand years ago. Tax is defined as <a compulsory levy, imposed by government or other tax raising body, on income, expenditure, or capital asset, for which the tax payer receives nothing specific in return(mohd, 2010). An attitude of fairness and trust are important tools for a tax administration in attempting to reduce incompliance. The key to establishing trust is to frame the collection of taxes to the population in a transparent manner and emphasize the perceived fairness of the approach taken .Norms \& the motivation to pay taxes are influenced by fairness both in how a person is treated by the administration individually and perceptions of fairness of the tax system in general(whether other people are also paying their fair share).If a tax administration can demonstrate its commitment in these areas ,there will be a compliance benefit(reason et.al,2009). Taxation in accordance with appropriately applied standards of ability to pay or benefits received is said to meet the requirements of vertical equity because such taxation exacts different amounts from people in different situations (parames waran, 2005).

Tax complexity may be responsible for the misperception of the tax system .In this study tax complexity is understood from two dimensions i.e excessive detail in the tax rules \& numerous computations required .At least a reasonable level of simplicity should be there because, tax payers come from various backgrounds, with differing level of education, income, and most importantly levels of tax knowledge. In helping tax payers to complete the tax returns accurately, the tax authority is responsible to come up with a simple, but sufficient tax return (martin et.al, 2010). Now a days two perspectives are available concerning tax efficiency. The classical perspective considers a tax system as efficient when it does not affect the different patterns of taxpayers behavior (jones, 2004). Ethiopia as developing country has continuously revising socio economic and civil service polices and proclamation based on the deriving nature of economic development. In this regard the government of Ethiopia has enacted the income tax proclamation number $979 / 2016$ to revise the previous proclamation which was effective since 2002. Hence, the main purpose of this study is to assess the tax payers' attitude towards the new tax system being implemented following the new income tax proclamation.

\subsection{Statement of the Problem}

As in all other countries, one of the purpose of taxation in Ethiopia is rising of as much revenue as possible to meet the ever -expanding expenditure for the supply of goods and services which are not available to the general public by the market (yohannes\&sisay,2009). It is clear that in order to be good, the tax should be fair. To be a fair tax, taxpayers should have the ability to pay and the tax itself should be characterized by its horizontal and vertical 
equitability. This means that when any tax system is unfair, that system as a whole will be considered by tax payers as bad tax system, and taxpayers will have negative attitude to that tax system (jones, 2007).

The absence of clear- cut objectives, programs, rules and regulations which have direct impact with the tax payers' knowledge and awareness intern brought about complex tax system (wubshet, 2010). Most tax payers think that the tax system itself is too complex, difficult to understand and the terminology used is unfamiliar to taxpayers (mohd, 2010). The tax system is described as efficient when it does not interfere with or influence taxpayers' economic behavior (jones, 2004). So a study on tax payers' attitude towards the tax system is important $\mathrm{b} / \mathrm{c}$ it has a serious influence on tax compliance.

There are a number of studies conducted on tax payers' attitude towards tax system. For instance, abdulhadi et.al, (2008), Amitai Etzioni (1986), and Roberts \&Hite (1994) were conducted their study on tax payers' attitude. However, all these researchers investigate tax payers' attitude for their respective countries. As per the researcher's knowledge, no study is conducted to examine tax payers' attitude towards the new tax proclamation in relation to tax fairness, tax efficiency and tax complexity in Ethiopia. Hence, this study attempted to examine the tax payers' attitude towards the new tax proclamation in relation to tax fairness, tax complexity and tax efficiency in Ethiopia with a particular emphasis of Employment income tax payers in Debre Markos Town.

\subsection{Objective of the Study}

The general objective of this study is to assess the tax payers' attitude towards the new tax proclamation in Ethiopia in case of employment income tax payers in Debre markos Town. To achieve this following specific objectives are dissected:

1. To examine taxpayers' attitude towards the tax fairness.

2. To evaluate whether the new tax proclamation is complex from taxpayers' point of view.

3. To examine whether the new tax proclamation is efficient from taxpayers' point of view.

\subsection{Significance of the Study}

This study is believed to be an input in improving the attitude of tax payers towards the new tax proclamation. Since the aim of this study is to investigate the tax payers' attitude, it gives some insights into how the tax authority creates awareness among the society to improve the tax payers' attitude. This study will assist the tax administration to identify aspects or areas where taxpayers experience challenges. Finally, this study believed to be relevant for further and future researchers.

\subsection{Scope of the Study}

This study attempted to investigate the tax payers' attitude towards the new tax proclamation. To make the study manageable and to evaluate the problem in detail, the researcher was only confined to the examination of "Employment income tax payers' attitude towards the new tax proclamation in Debre Markos Town, Ethiopia.

\section{Literature Review}

\subsection{Tax System}

Tax is defined as a compulsory levy or contribution made by the public to the government for which nothing directly is received in return or without a quid pro quo (song \& Yarbrough, 1978). As stated by Strauss \& Hyun (2001), the first goal of a tax system in any democracy government is to finance budgetary programs through spending for public goods such as national defense, infrastructure such as roads and education and providing an income maintenance system which meet the social objectives. Tax payers' attitude towards taxation is crucial in any tax systems success to achieve compliance.

\subsection{Tax Fairness}

To be considered as a fair tax system, tax payers should have the ability to pay their tax burden. Ability to pay means that underline the literature of taxes, the economic resources of a tax payer should be under his/her control. When a tax system is designed so that individuals with the same ability to pay owe the same amount of tax, it can be described as horizontally equitable, while when it is designed so that individuals with greater ability to pay owe more tax than individuals with lower ability to pay, it is considered vertically equitable (Jones, 2004). Torgler, (2001) mentioned that tax fairness is a very important factor influencing tax payers compliance behavior because it is related to tax burdens for any good tax system tax fairness is crucial. Bordignon (1993) introduced fairness as an additional motivation to tax evasion or non compliance. When there is lack of equity in an exchange relationship it creates a sense of distress, with this anger it leads to a reaction which canrestore equity, which is tax evasion or tax non compliance. Fairness is difficult to define because of the four inherent problems: (1) It is multi dimensional, (2) It can be defined at the individual level or for the society at large, (3) Fairness is intertwined with complexity and (4) A lack of fairness maybe perceived justification or a cause of non compliance (Christensen et al, 1994). 


\subsection{Tax Efficiency}

Tax systems efficiency is important, especially because the term of efficiency is used in two different perspectives under the context of taxation. The first one describes a tax system as efficient when it does not interfere with or influence tax payers economic behavior. Two perspectives are available now a days concerning tax efficiency. The classical perspective considers a tax system as efficient when it does not affect the different patterns of tax payers' behavior. Based on this perspective, tax is not purposive, so it is imposed and collected just to generate revenue for governments. According to this perspective, a tax that is designed to modify tax payers' behavior is considered in efficient because it distorts the market. The classical economist, Adam smith, believed that a tax system should have as little as possible influence on tax payers (Jones, 2004). The way tax payers believe a tax system is an important issue, because it determines the level of tax payers' compliance, and their level of cooperation. Moreover, a tax system determines people's loyalty to their government (Ibrahim et.al, 2009).

\subsection{Tax Complexity}

The complexity of a decision problem can be characterized by the variety of influencing factors and by the extent of their dependence. Tax complexity may be responsible for the misperception. Congdon et.al, 2009 claim that, individual will respond not to the tax rate as it is set but as they construe it. Conceivably, more complex a tax system is the large may be this difference between the legal tax and constructed tax. As a result, this bias can affect real decision problem. However, additional information reduces complexity and receipts adjust their behavior (Fochmann et.al, 2010). There is almost certainly likely to be universal agreement among tax academics and practitioners that tax complexity is itself a complex concept. It is widely regarded as multi facetted concept that cannot be simultaneously and adequately characterized by a single definition or measure. An implication of the multi dimensionality of tax complexity is that it is basically comparative concept. Although the concept of tax complexity is widely used and much discussed, with the compliant always being made that tax system is too complex no one ever complains that the system is not complex enough the concept turns out to be a bit more elusive when one tries to pin it down. Certainly it is a concept that doe not figure in standard economic analysis of tax system, and has not been given any very precise definition. We think much of the popular discussion of tax complexity uses the term complexity as a catch - all term that might encompass a number of different features such as lack of transparency rather than complexity (ulph, 2013).

\section{Methodology of the Study 3.1 Research Design}

Researches can be done through different types of researches' design such as explanatory, exploratory, descriptive and casual. Hence, since the main objective of this paper is to assess the attitude of tax payers towards fairness descriptive research design is used and results are discussed using qualitative research approach.

\subsection{Data and Data Source}

In this study the researcher was used primary data. Data were collected through a five degree likert scale self administered questionnaires.

\subsection{Target Population}

The target population for the survey study is employment income taxpayers who are subject for employment tax. Government and nongovernment employees in Debre markos Town were used as participants in the survey study. Total employment taxpayers in Debre markos Town are 2775 as per the information obtained from Debre markos Town Public service and Human resource office.

\subsection{Sampling Technique}

In deciding the desired sample size, it is customary to consider the availability of time, resources and the aim of the research. In this regard, taking the available resources, time and budget in to account, a sample size of 96 is found to be feasible from 2775 employment tax payers found in Debre markos Town. In order to determine the sample size yemane, (1967) sample size determination formula is used with $90 \%$ of confidence level and $10 \%$ level of significance. After determining the sample size respondents were selected using simple random sampling technique.

$$
\mathrm{n}=\mathrm{N} / 1+\mathrm{N}(\mathrm{e})^{2}
$$

Where; " $\mathrm{n}$ " is the sample size, "e" level of significance and " $\mathrm{N}$ " is target population.

\subsection{Method of Data Analysis and Presentation}

After administering and scoring research tools, scripts, data was collected and organized. In this study the collected data were analyzed using descriptive statistical analysis techniques. Descriptive analysis showed how the taxpayers perceive the new tax proclamation to tax fairness, tax complexity and tax efficiency. In this analysis basic features 
of the survey data are presented by using tables and percentages.

\section{Results and Discussion}

This chapter deals with the presentation of data analysis, findings and interpretation. The purpose of this study was to assess taxpayers' attitude towards the new tax proclamation and it is mainly focus on tax payers' attitude towards tax fairness, tax complexity and tax efficiency.

\subsection{Taxpayers Attitude towards Horizontal Fairness}

The respondents were asked whether they believe that it is fair for individuals with similar amounts of employment income to pay similar amount of employment income tax or not. The tax payers' survey outcome revealed that out of the 85 respondents 60 percent of them agreed that it is fair for individuals with similar amount of employments income to pay similar amount of employment income tax. This implies that majority of tax payers believed that, it is fair for individuals with similar amount of employments income to pay similar amount of employment income tax. From this the researcher can conclude that it is fair for them to pay similar share of employment income tax compared with other similar employment income earners.

\subsection{Taxpayers Attitude towards Vertical Fairness}

To investigate the tax payers' attitude towards vertical fairness, respondents were asked whether they believe that it is fair that high employment income earners are subject to tax at progressively higher tax rates than low employment income earners or not. As a result, out of 85 respondents 69.4 percent of them agreed that, they believe it is fair if high income earners are subject to tax at progressively higher tax rates than low income. The majority of tax payers believed that it is fair if high income earners are subject to tax at progressively higher tax rates than low income earners. Respondents were asked whether they believe that it is fair if low income earners are taxed at a lower rate than middle income earners or not. As a result, 65.88 percent of the respondents were agreed that it is fair if low income earners are taxed at a lower rate than middle income earners. Hence, majority of the tax payers believed that, it is fair if low income earners are taxed at a lower rate than middle income earners. Furthermore, the survey indicated that majority of tax payers believe the new tax proclamation as fair in terms of vertical fairness.

\subsection{Taxpayers Attitude towards Administrative Fairness}

In respect of knowing respondents attitude about administrative fairness, the outcome of the employment income tax payers survey revealed that majority of tax payers believed that, the government is utilizing reasonable amount of tax revenue to achieve social goals. Regarding to tax payers' attitude towards tax administration, the survey outcome revealed that the majority of tax payers believed that, the administration of the tax system by tax authority is not consistence across tax payers. With regard to tax payers' attitude about the government expenditure, the survey result indicated that the majority of tax payers believed that the government does not spend too much tax revenue on unnecessary welfare assistance. Thus, the majority of tax payers believed that, the tax system is fair in terms of administrative fairness.

\subsection{Taxpayers Attitude towards Tax Complexity}

Respondents were asked to measure the tax payer's attitude towards tax complexity and more than $50.58 \%$ of them were agreed that the rules related to employment income tax are clear and understandable. Therefore, based on the survey the majority of the tax payers believed that, the rules related to employment income tax are clear and understandable. With regard to procedural complication, the outcome of the survey revealed that, the majority of tax payers believed that, the tax system is tedious in procedural complications for tax purposes. The respondents are also asked whether the tax system is complicated or not. In respect of knowing their attitude the outcome of the tax payers survey indicated that, a higher percentage of tax payers believe that, the Ethiopian tax system is too complicated.

\subsection{Taxpayers Attitude towards Tax Efficiency}

The respondents were asked whether they believe that, the Ethiopian tax system encourage tax payers for investment or not. The survey result indicated more than $75 \%$ of respondents believe that, the new tax proclamation does not encourage tax payers for investment. The respondents are also asked for whether they think that, the government of Ethiopia increases the tax rate under the condition of inflation. The outcome of survey revealed that, the highest percentage of taxpayers believed that, the government of Ethiopia does not increase the tax rate under the condition of inflation. In respect of knowing tax payers attitude towards encouragement made by the new tax proclamation for tax payers, the survey outcome indicates about 55.28 percent of respondents believed that, the current Ethiopian tax system does not encourage tax payers. Hence, it can be concluded that the Ethiopian new tax proclamation is economically inefficient Respondents were also asked whether they believe that, the new tax proclamation increases the saving and consumption habit of employees or not. In this regard, 60 percent of the 
respondents replayed that the tax system does not encourage taxpayers to save. This implies that, the new tax proclamation does not encourage taxpayers for saving.

\section{Conclusion}

The survey result revealed that Tax payers believe the new tax proclamation as reasonably fair in terms of vertical, horizontal and administrative fairness. On the other hand, these tax payers believe that the new tax proclamation is complex and economically in efficient. However, it does not mean that the new tax proclamation is fair, complex and economically in efficient at all, rather it is to mean that the new tax proclamation is fair but complex and in efficient in mind of tax payers. They also believed that the new tax proclamation is economically in efficient. Because, the new tax proclamation does not encourage tax payers for investment.

In relation to saving habit the tax payers believed that, the new tax proclamation does not encourage the saving habit. This means that in comparison to standard of living the reduction of tax rate does not encourage saving.

\section{Recommendation}

Based on the findings of the study the following recommendations are forwarded.

$>$ To change the attitude of tax payers the tax authority shall empower them with knowledge and training through sustainable awareness creation programs

$>$ There should be more preventive education for the public and increased awareness of tax responsibilities in schools.

$>$ The tax authority shall try to make the tax law and procedures simple, understandable and transparent to tax payers; because, it is worthless to be actually efficient, fair and simple unless the tax system is efficient, fair and simple in the minds of tax payers.

$>$ The tax authority should support tax payers by increasing the exempted amount of income in order to promote saving.

\section{REFERENCES}

A.L. Christensen; and S.G weihrich (1996). Tax fairnes; different roles, different perspectives, pp. 63-94.

Abdullah Al-momani (2008). Income tax fairness and taxpayers compliance in Jordan journal of economic and administrative science vol.24, No. 1, (14-39).

Adams T. S. (1921). Fundamental problems of federal income taxation.

Bartolome, C.A.de (1995). Which tax rate do people use: Average or Marginal?; journal of public economics 56, 79-96.

Congdon,W; J.R. Kling and S.mullainothan (2009). Behavior, economics and tax policy, National tax journal 62 , 375-386.

Creswell, JW (2003). Research design: Qualitative, Quantitative and mixed methods approaches, 2nd ed sage publications, California.

David Ulph (2013), measuring tax complexity,research non.

Desta Kassa Weldegiorgis, (2010). Assessment of taxpayers' voluntary compliance with taxation: a case of Mekelle city, Tigray, Ethiopia, Mekelle University

Gunther D.A., (1994). "Earnings Management in Response to Corporate Tax Rate Changes: Evidence from the 1986 Tax Reform Act", The Accounting Review, Vol. 69, No. 1. , pp. 230-243.

Helhel, Y. \& Ahmed, Y. (2014). Factors Affecting Tax Attitudes and Tax Compliance: A Survey Study in Yemen; European Journal of Business and Management ; Vol.6, No.22; retrieved from www.iiste.org

James, A., Brain, E. \& Jonathan, F. (1998). Tax compliance. Journal for economic literature vol.36 pp. 818-860

Lamb M., Nobes C., and Roberts A., (1998). "International variations in the Connection Between Tax and Financial Reporting", Accounting and Business Research, Vol 28, p.p. 173-188.

Lev B. and Nissim D., (2004). "Taxable Income, Future Earnings and Equity Values", The Accounting Review, Vo. 29, No. 4, p.p. 1039-1074

Loo,C., \& McKerchar,M. (2010). Challenges in understanding compliance behavior of taxpayers in Malaysia. Asian Journal of Business and Accounting, 3(2), 2, ISSN 1985-4064

Maydew E. L., (1997). "Tax-Induced Earnings Management by Firms with Net Operating Losses", Journal of Accounting Research, Vol. 35, No. 1, p.p. 83-96.

Miller G.S. and Skinner D.J., (1998). "Determinants of the Valuation Allowance for Deferred Tax Assets under SFAS 109”, The Accounting Review, Vol. 73, No. 2., pp. 213-233.

Pope T. R., (1979). "A Flowchart Analysis of the Federal Income Tax Concept of Earnings and Profits", The Accounting Review, Vol. 54, No. 1., pp. 163-169.

Shackelford D. and Shevlin T., (2001). "Empirical Tax Research in Accounting”, Journal of Accounting and Economics, Vol 31, N 3, p.p. 321-387 


\section{Note}

Table 1 response of respondents on fairness, efficiency, and complexity of the tax system $(n=85)$

\begin{tabular}{|c|c|c|c|c|}
\hline Number & Horizontal fairness & Measures & Frequency & Percentage \\
\hline \multirow[t]{6}{*}{1} & \multirow{6}{*}{$\begin{array}{l}\text { It is fair for individuals with similar } \\
\text { amount of employment income to pay } \\
\text { similar amount of tax }\end{array}$} & Strongly agree & 21 & 24.7 \\
\hline & & Agree & 30 & 35.3 \\
\hline & & Neutral & 17 & 20 \\
\hline & & Disagree & 17 & 20 \\
\hline & & Strongly dis agree & 0 & 0 \\
\hline & & Total & 85 & 100 \\
\hline \multirow[t]{6}{*}{2} & \multirow{6}{*}{$\begin{array}{l}\text { I believe that it is fair for me to pay similar } \\
\text { share of employment income tax compared } \\
\text { with other similar employment income } \\
\text { earner }\end{array}$} & St. agree & 13 & 15.3 \\
\hline & & Agree & 30 & 35.3 \\
\hline & & Neutral & 17 & 20 \\
\hline & & Disagree & 21 & 24.7 \\
\hline & & Strongly disagree & 4 & 4.7 \\
\hline & & Total & 85 & 100 \\
\hline No & Vertical fairness & Measures & Frequency & Percentage \\
\hline \multirow[t]{6}{*}{1} & \multirow{6}{*}{$\begin{array}{l}\text { It is fair that high employment income } \\
\text { earners are subject to tax at progressively } \\
\text { higher tax rates than low employment } \\
\text { income earners. }\end{array}$} & Strongly agree & 21 & 24.7 \\
\hline & & Agree & 38 & 44.7 \\
\hline & & Neutral & 0 & 0 \\
\hline & & Disagree & 26 & 30.58 \\
\hline & & Strongly disagree & 0 & 0 \\
\hline & & Total & 85 & 100 \\
\hline \multirow[t]{6}{*}{2} & \multirow{6}{*}{$\begin{array}{l}\text { It is fair that low employment income } \\
\text { earners are taxed at lower rate than middle } \\
\text { employment income earners. }\end{array}$} & Strongly agree & 26 & 30.58 \\
\hline & & Agree & 30 & 35.3 \\
\hline & & Neutral & 8 & 9.4 \\
\hline & & Disagree & 21 & 24.7 \\
\hline & & Strongly disagree & 0 & 0 \\
\hline & & Total & 85 & 100 \\
\hline No & Administrative fairness & Measures & Frequency & Percentage \\
\hline \multirow[t]{6}{*}{1} & \multirow{6}{*}{$\begin{array}{l}\text { I believe that the gov't } \\
\text { collects a reasonable amou } \\
\text { nt of tax to achieve social } \\
\text { goals }\end{array}$} & Strongly agree & 17 & 20 \\
\hline & & Agree & 26 & 30.58 \\
\hline & & Neutral & 0 & 0 \\
\hline & & Disagree & 34 & 40 \\
\hline & & Strongly disagree & 8 & 9.4 \\
\hline & & Total & 85 & 100 \\
\hline \multirow[t]{6}{*}{2} & \multirow{6}{*}{$\begin{array}{l}\text { The administration of tax system is } \\
\text { consistence across tax payers }\end{array}$} & Strongly agree & 0 & 0 \\
\hline & & Agree & 26 & 30.58 \\
\hline & & Neutral & 4 & 4.7 \\
\hline & & Disagree & 34 & 40 \\
\hline & & Strongly disagree & 21 & 24.7 \\
\hline & & Total & 85 & 100 \\
\hline \multirow[t]{6}{*}{3} & \multirow{6}{*}{$\begin{array}{l}\text { I think the government spends too much } \\
\text { tax revenue on unnecessary welfare } \\
\text { assistance }\end{array}$} & Strongly agree & 8 & 9.4 \\
\hline & & Agree & 13 & 15.3 \\
\hline & & Neutral & 34 & 40 \\
\hline & & Disagree & 17 & 20 \\
\hline & & Strongly disagree & 13 & 15.3 \\
\hline & & Total & 85 & 100 \\
\hline
\end{tabular}




\begin{tabular}{|c|c|c|c|c|c|c|}
\hline \multicolumn{2}{|c|}{ Number } & \multicolumn{2}{|l|}{ Horizontal fairness } & Measures & Frequency & Percentage \\
\hline \multicolumn{2}{|c|}{ No } & \multicolumn{2}{|c|}{ Tax efficiency } & Measures & Frequency & Percentage \\
\hline \multirow{6}{*}{\multicolumn{2}{|c|}{1}} & \multirow{6}{*}{\multicolumn{2}{|c|}{$\begin{array}{l}\text { I believe that the Ethiopian tax system } \\
\text { encourage tax payers in investment }\end{array}$}} & Strongly agree & 0 & 0 \\
\hline & & & & Agree & 8 & 9.4 \\
\hline & & & & Neutral & 13 & 15.3 \\
\hline & & & & Disagree & 47 & 55.3 \\
\hline & & & & Strongly disagree & 17 & 20 \\
\hline & & & & Total & 85 & 100 \\
\hline \multirow{6}{*}{\multicolumn{2}{|c|}{2}} & \multirow{6}{*}{\multicolumn{2}{|c|}{$\begin{array}{l}\text { I think that the government of Ethiopia } \\
\text { increases the tax rate under the condition of } \\
\text { inflation }\end{array}$}} & Strongly agree & 4 & 4.7 \\
\hline & & & & Agree & 30 & 35.3 \\
\hline & & & & Neutral & 17 & 20 \\
\hline & & & & Disagree & 26 & 30.58 \\
\hline & & & & Strongly disagree & 8 & 9.4 \\
\hline & & & & Total & 85 & 100 \\
\hline 3 & & I see that, current Ethiopian & $\operatorname{tax}$ & Strongly agree & 0 & 0 \\
\hline & & proclamation encourage tax payers & & Agree & 17 & 20 \\
\hline & & & & Neutral & 21 & 24.7 \\
\hline & & & & Disagree & 38 & 44.7 \\
\hline & & & & Strongly disagree & 9 & 10.58 \\
\hline & & & & Total & 85 & 100 \\
\hline No & & Tax complexity & & Measures & Frequency & Percentage \\
\hline 1 & & The rules related to employment in & come & Strongly agree & 17 & 20 \\
\hline & & tax are clear and understandable & & Agree & 26 & 30.58 \\
\hline & & & & Neutral & 8 & 9.4 \\
\hline & & & & Disagree & 21 & 24.7 \\
\hline & & & & Strongly disagree & 13 & 15.3 \\
\hline & & & & Total & 85 & 100 \\
\hline 2 & & I find tedious in procedural complic & ations & Strongly agree & 0 & 0 \\
\hline & & for tax purpose & & Agree & 34 & 40 \\
\hline & & & & Neutral & 26 & 30.58 \\
\hline & & & & Disagree & 13 & 15.3 \\
\hline & & & & Strongly disagree & 12 & 14.11 \\
\hline & & & & Total & 85 & 100 \\
\hline 3 & & Ethiopian employment income tax & is too & Strongly agree & 4 & 4.7 \\
\hline & & much complicated & & Agree & 34 & 40 \\
\hline & & & & Neutral & 21 & 24.7 \\
\hline & & & & Disagree & 17 & 20 \\
\hline & & & & Strongly disagree & 9 & 10.58 \\
\hline & & & & Total & 85 & 100 \\
\hline 4 & & The Ethiopian employment incom & e $\operatorname{tax}$ & Strongly agree & 13 & 15.3 \\
\hline & & rules are bulky and hard for tax paye & & Agree & 3 & 35.3 \\
\hline & & & & Neutral & 4 & 4.7 \\
\hline & & & & Disagree & 26 & 30.58 \\
\hline & & & & Strongly disagree & 12 & 14.11 \\
\hline & & & & Total & 85 & 100 \\
\hline no & State & ment & Meas & & uency & Percentage \\
\hline 1 & The & new tax proclamation increases the & Yes & & 34 & $40 \%$ \\
\hline & $\begin{array}{l}\text { savi } \\
\text { emp }\end{array}$ & $\begin{array}{l}\text { ig and consumption habit of } \\
\text { oyees }\end{array}$ & No & & 51 & $60 \%$ \\
\hline 2 & & new tax proclamation Is fair & Yes & & 30 & $35.3 \%$ \\
\hline & com & pared to the former tax system & No & & 55 & $64.7 \%$ \\
\hline
\end{tabular}

Source: survey result 2018 